\title{
A New Era for Mild Strain Cross-Protection
}

\author{
Katrin Pechinger ${ }^{1,+}$, Kar Mun Chooi ${ }^{1,+}$, Robin M. MacDiarmid ${ }^{1,2}{ }^{\oplus}$, Scott J. Harper ${ }^{3}$ and \\ Heiko Ziebell ${ }^{4, *(\mathbb{D})}$ \\ 1 The New Zealand Institute for Plant and Food Research Limited, Auckland 1142, New Zealand \\ 2 School of Biological Sciences, University of Auckland, Auckland 1142, New Zealand \\ Department of Plant Pathology, Washington, State University, Prosser, WA 99350, USA \\ 4 Julius Kühn Institute, Institute for Epidemiology and Pathogen Diagnostics, Messeweg 11-12, \\ 38104 Braunschweig, Germany \\ * Correspondence: heiko.ziebell@julius-kuehn.de; Tel.: +49-531-299-3802 \\ + These authors contributed equally.
}

Received: 19 June 2019; Accepted: 14 July 2019; Published: 23 July 2019

\begin{abstract}
Societal and environmental pressures demand high-quality and resilient cropping plants and plant-based foods grown with the use of low or no synthetic chemical inputs. Mild strain cross-protection (MSCP), the pre-immunization of a plant using a mild strain of a virus to protect against subsequent infection by a severe strain of the virus, fits with future-proofing of production systems. New examples of MSCP use have occurred recently. New technologies are converging to support the discovery and mechanism(s) of action of MSCP strains thereby accelerating the popularity of their use.
\end{abstract}

Keywords: cross-protection; mild strain cross-protection; plant protection

\section{Societal and Environmental Pressures for Resilient Cropping Plants}

Multiple and significant global trends are currently demanding for highly sustainable, reliable, and increasingly efficient production of plant crops. Our response to the specter of climate change drives the need for reduced greenhouse gas emissions e.g., in the production or use of synthetic chemicals for insect management, and the need to be able to grow crops under progressively extreme climatic conditions [1,2]. World population growth drives the need for increased food production on less land as more people require housing and infrastructure [3]. Adding to the demands on plant production, there is a move to healthier and more sustainable sources of protein from plants rather than meat, and plant crops are the main sources of increasing biofuel production [4]. Sustainable production methods that reduce the need for synthetic chemicals are desired to reduce habitat degradation and harm to people [5]. The world's increasing middle class population can afford high-quality sustainably produced food, while the world's poorest population require secure food supplies at lowest costs [6]. Sustainable production of plant-based food is required to care for the environment and for future generations of people [7].

While viruses are the major pathogen causing emerging infectious diseases in plants worldwide, we have a few methods to manage the crop viruses [8]. Furthermore, it is the world's poorest people who depend on the staple crops that often suffer from devastating losses because of virus infections. Even in industrialized countries, plant viruses cannot be managed easily. To meet the United Nation's Sustainable Development goal 2, Zero Hunger, we need to implement crop virus management methods [9]. We believe that now is the era for mild strain cross-protection (MSCP), which once established can provide "low tech" and sustainable protection against pathogenic viruses of crop plants. 
Cross-protection, also known as "pre-immunization" is a method of plant virus control, whereby a plant is deliberately infected with a mild strain of a virus in order to protect the plant against damage caused by a more severe ("challenge") strain of the same virus [10]. MSCP provides a sustainable pathway among many needed to address both the societal and ecological resilience that will "increase the crop production while reducing unsustainable uses of water, nutrients, and agricultural chemicals" [11,12].

When naturally occurring mild strains are used, MSCP is not burdened with the social acceptability issues of genetic modification or gene editing. However, the use of MSCP does need to retain social license for growers and consumers. Social license cannot be assumed [13]. As such, several requirements to ensure long-lasting protection using MSCP have been identified [14]. Importantly, experimental demonstration of the protection afforded by the mild strain, its durability and impact on the crop and other hosts of the virus, among other safeguards detailed previously, must be undertaken in a rigorous manner [14]. To our knowledge, no report has been published describing the "escape" of a mild cross-protecting virus strain into the "wild" and causing severe symptoms on non-target hosts. This risk appears to be very low in comparison to the reported cases where MSCP broke down after a while due to the arrival of "novel" more severe challenge strains, incomplete spread within the host plant, or the occurrence of new viral vectors [15-21]. Therefore, only close working relationships between the crop producers and scientists can ensure the identification of mild strains of viruses (and the severe strains they protect against) and the durable use of MSCP in crop production systems. Open communication including information for general and specialized audiences about the uses, risks, and control measures for MSCP maintains the confidence of producers, consumers, and the public about its environmentally friendly and people-safe use in crop production.

\section{What Is Mild Strain Cross-Protection?}

Cross-protection is usually only effective between closely related strains of the same virus, although there are cases where phylogenetically distinct viruses can protect against each other, for example citrus vein enation virus was reported to protect against citrus tristeza virus (CTV) [22]. Exploiting the fact that cross-protection only occurred between closely related viruses, cross-protection was used historically as a virus diagnosis and characterization tool before the serological and nucleic acid-based methods were available. Supporting the MSCP for closely related species, Folimonova demonstrated that cross-protection is only effective between CTV isolates belonging to the same strain [23].

The traditional approach for identification of isolates for cross-protection involves identifying individual plants that display only mild symptoms, or remain symptomless, in fields where other neighboring plants display severe symptoms correlated with viral infection. Next, virus(es) are isolated from these individual plants; it should be noted that one part, limb or side of a plant may display mild symptoms while the rest of the plant exhibits severe symptoms, potentially indicating different sub-populations distributed throughout the individual plant [24]. These viruses are first isolated, then used to inoculate the target host of choice that is subsequently challenged with known pathogenic isolates. This challenge may be deliberate, through simultaneous or staggered mechanical, graft, or vector inoculation, or the putative protective isolate may be exposed to natural infection under field conditions over an extended period of time.

When searching for potential cross-protective isolates, one should consider that an isolate may only "protect" one host cultivar, for example in citrus the CTV cross-protective isolate IAC protects Pear sweet orange but not Hamlin or Valencia [25]. Furthermore, protection may be limited to pathogenic isolates present in one geographic location; the IAC isolate has provided stable protection in Sao Paulo state, but not the neighboring state of Paraná in Brazil [26,27].

Another method for selecting attenuated strains is by passing a viral population that may be a composite of many strains through an alternative host. Sometimes the predominant strain within the population changes through this virus-host interaction. Reasons for this may be that the alternative host is resistant to some strains of the virus and prohibits the replication and/or movement of such 
strains while others are able to move through the plant more rapidly. This technique was used by Yeh and Cheng [28] who used Cucumis metuliferus as an alternative host to obtain mild strains of papaya ringspot virus-P from nitrous acid-induced mild strains HA5-1 and HA6-1.

Attenuated (mild) strains may also be selected through thermal treatment of infected plants; in this way a heat-attenuated mild strain of CTV was discovered [29]. Additionally, mutagenic agents or DNA recombination can be used to create mild strains in the laboratory.

High-throughput sequencing (HTS) is a promising tool for the discovery of potential cross-protective isolates. HTS can rapidly identify the genotypic composition of the virus or viruses present [30-32]; a necessary precondition for both like-for-like superinfection exclusion [23] and population-interaction cross-protective mechanism hypotheses. Moreover, HTS permits the comparison, at the sequence level, between the prospective mild protective and pathogenic challenge isolates. However, there are limitations with this approach. The data represent a "snapshot" in space and time, that is, the virus or viruses present in a single plant sample. This is not necessarily representative of the entire plant because of variable titer and distribution, virus tropism, and/or seasonal fluctuations [33]. Furthermore, sequence data alone cannot, without knowledge of the mechanism of cross-protection in the plant host in question, identify what a given isolate can protect against. Finally, and most critically, HTS and subsequent bioinformatic analyses cannot yet reveal the biological properties of an isolate, i.e., whether it is pathogenic, and/or in what hosts it is able to replicate [34].

\section{Mild Strain Cross-Protection-Discovery through to Examples from Laboratory and Field Cross-Protection}

Folimonova [16] laid out a "recipe" for the cross-protection by CTV that outlines how a protective mild strain can be found and isolated; their approach involves biological characterization of severe and mild isolates and suggestions for separating individual genotypes. While their approach is specific to CTV, their "recipe" can be applied to other plant viruses.

The cross-protection phenomenon was observed almost a century ago [35-38] and has since seen multiple examples from various virus/crop combinations, in depth reviewed by Ziebell and Carr [10]. The past decade has witnessed a resurgence of MSCP with efficacy demonstrated in the research environment as well as field-deployed protection (Table 1). Examples of mild strains are given below as case studies to illustrate the methods to discover and select for mild strains, to commercialize the mild strains, and to examine potential mechanisms of MSCP. 
Table 1. Protective virus isolates and their respective challenging isolates tested for their mild strain cross-protection capabilities. Host plants used to study the interaction of the protecting and challenging isolates, as well as the test site (Lab* and/or Field) are given. Viruses are listed according to the genus of the protecting virus.

\begin{tabular}{|c|c|c|c|c|c|}
\hline Protecting Virus & Challenging Virus & Host Plant & Test Site & Year of Publication & Reference \\
\hline \multicolumn{6}{|l|}{ Alfamovirus } \\
\hline Alfalfa mosaic virus (AMV), strain 425 & AMV, T6 strain & Phaseolus vulgaris & $\mathrm{Lab}$ & 1995 & [39] \\
\hline \multicolumn{6}{|l|}{ Badnavirus } \\
\hline $\begin{array}{l}\text { Cocoa swollen shoot virus (CSSV), N1 and } \\
\text { SS365B isolates }\end{array}$ & CSSV, 1A isolate & Theobroma cacao various cultivars & Field & 2016 & [40] \\
\hline \multicolumn{6}{|l|}{ Carmovirus } \\
\hline Turnip crinkle virus, TCV $\triangle \mathrm{CP}$ & TCV, T1d1 & Arabidopsis thaliana & Lab & 2014 & [41] \\
\hline \multicolumn{6}{|l|}{ Caulimovirus } \\
\hline Cauliflower mosaic virus (CaMV), UN130 isolate & CaMV, Cabb S strain & Brassica rapa & Lab & 1989 & [42] \\
\hline \multicolumn{6}{|l|}{ Closterovirus } \\
\hline Citrus tristeza virus (CTV), T30 isolates & Citrus vein enation virus & Citrus aurantifolia cv. Mexican lime & Lab & 2004 & [43] \\
\hline CTV, CS-1 isolate & CTV, Rolândia strain & Citrus sinensis & Field & 2013 & [44] \\
\hline CTV, GFMS-12, GFMS-35, and LMS-6 strains & CTV severe strains & $\begin{array}{l}\text { C. paradisi Macfad., C. aurantifolia, C. sinensis, C. } \\
\text { reticulata }\end{array}$ & Field & 2010,2015 & {$[45,46]$} \\
\hline CTV & CTV & $\begin{array}{c}\text { Citrus sinensis various cultivars, Citrus } \times \text { paradisi } \\
\text { various cultivars }\end{array}$ & Field & 2010 & [47] \\
\hline \multicolumn{6}{|l|}{ Cucumovirus } \\
\hline Cucumber mosaic virus (CMV), S strain & CMV, P strain & $\begin{array}{l}\text { Solanum lycopersicum cv Rutgers, Nicotiana } \\
\text { tabacum cvs Xanthi-n, Turkish, Cucurbita pepo } \\
\text { Solanum lycopersicum, various cultivars, }\end{array}$ & Field & 1985 & [48] \\
\hline CMV-S with S-CARNA 5 & CMV severe strains & $\begin{array}{c}\text { Cucurbita melo cv. Janus des Canaries, Capsicum } \\
\text { annum cv. California Wonder }\end{array}$ & Field & 1991,1998 & {$[49,50]$} \\
\hline $\mathrm{CMV}, \mathrm{KO} 2$ strain & Severe strain CMV-876 & Solanum lycopersicum & Lab & 1993 & [51] \\
\hline CMV, CM95 strain & CMV severe strains & Cucumis sativus cv. Sagamihanjiro & Lab & 1997 & [52] \\
\hline Tomato aspermy virus (TAV) mild strain & TAV severe strains & Solanum lycopersicum, various cultivars & $\mathrm{Lab}$ & 1986 & [53] \\
\hline
\end{tabular}


Table 1. Cont.

\begin{tabular}{|c|c|c|c|c|c|}
\hline Protecting Virus & Challenging Virus & Host Plant & Test Site & Year of Publication & Reference \\
\hline \multicolumn{6}{|l|}{ Furovirus } \\
\hline Beet soilborne mosaic virus & Beet necrotic yellow vein virus & Beta vulgaris & $\mathrm{Lab}$ & 1999 & [54] \\
\hline \multicolumn{6}{|l|}{ Carlavirus } \\
\hline Potato virus $\mathrm{M}(\mathrm{PVM}), \mathrm{I}-38$ isolate & PVM, Uran isolate & Datura metel & Lab & 2016 & [55] \\
\hline \multicolumn{6}{|l|}{ Geminivirus } \\
\hline African cassava mosaic virus (ACMV) - Uganda & Virulent ACMV strains & Manihot esculenta & Field & 2004 & [56] \\
\hline African cassava mosaic virus (ACMV) & $\begin{array}{l}\text { East African cassava mosaic } \\
\text { Cameroon virus (EACMVC) }\end{array}$ & Nicotiana benthamiana & $\mathrm{Lab}$ & 2012 & [57] \\
\hline Apple mosaic virus (ApMV), mild strain "M" & ApMV, severe strain "A" & Malus $s p$. , various cultivars & Field & 1964 & [58] \\
\hline \multicolumn{6}{|l|}{ Luteovirus } \\
\hline Barley yellow dwarf virus (BYDV), mild isolates & BYDV severe strains & Avena sativa var. Clintland 64 & Lab & 1965,1991 & {$[59,60]$} \\
\hline Potato leaf roll virus (PLRV), mild strain & PLRV severe strain & Solanum tuberosum 'Katahdin' Physalis floridana & $\mathrm{Lab}$ & 1955 & [61] \\
\hline \multicolumn{6}{|l|}{ Macluravirus } \\
\hline $\begin{array}{l}\text { Chinese yam necrotic mosaic virus (CYNMV), } \\
\text { KM3 strain }\end{array}$ & CYNMV wild-type & Dioscorea opposita & Field & 2015 & [62] \\
\hline \multicolumn{6}{|l|}{ Nepovirus } \\
\hline Arabis mosaic virus (ArMV), Ta strain & GFLV severe strain & $\begin{array}{l}\text { Vits vinifera cv. Gewurztraminer clone } 643 \\
\text { grafted onto rootstock Kober } \\
\text { 5BB clone 259., V. vinifera, various cultivars }\end{array}$ & Field & 2008,1993 & {$[63,64]$} \\
\hline $\begin{array}{l}\text { Tomato ringspot virus (ToRSV), Chickadee } \\
\text { isolate }\end{array}$ & ToRSV, PYBM isolate & Nicotiana benthamiana & Lab & 1988 & [65] \\
\hline \multicolumn{6}{|l|}{ Potexvirus } \\
\hline $\begin{array}{c}\text { Pepino mosaic virus (PepMV), LP,EU, and CH2 } \\
\text { strains }\end{array}$ & Severe PepMV, CH2 isolate & Solanum esculentum cv. Tricia & Lab & 2010 & [66] \\
\hline $\begin{array}{l}\text { PepMV, VX1, and VC1 mixture (LP and CH2 } \\
\text { genotype) }\end{array}$ & $\begin{array}{l}\text { Severe PepMV isolates of EU } \\
\text { and CH2 genotype }\end{array}$ & Solanum esculentum various cultivars & $\mathrm{Lab}$ & 2017 & [67] \\
\hline PepMV, Sp13, and PS5 & $\begin{array}{l}\text { Severe PepMV isolates of EU } \\
\text { and CH2 genotype }\end{array}$ & Solanum esculentum various cultivars & Field & 2018 & [68] \\
\hline PepMV, KD strain (engineered) & PepMV, wild-type & $\begin{array}{l}\text { Nicotiana benthamiana, } \\
\text { Solanum esculentum various cultivars }\end{array}$ & Lab & 2015 & [69] \\
\hline Potato virus $\mathrm{X}(\mathrm{PVX})$, mild strain & PVX severe strain & Nicotianatabacum & $\mathrm{Lab}$ & 1933 & [36] \\
\hline PVX E1001A, E46A & Wild type PVX severe strain & Nicotiana benthamiana & $\mathrm{Lab}$ & 2019 & [70] \\
\hline
\end{tabular}


Table 1. Cont.

\begin{tabular}{|c|c|c|c|c|c|}
\hline Protecting Virus & Challenging Virus & Host Plant & Test Site & Year of Publication & Reference \\
\hline \multicolumn{6}{|l|}{ Potyvirus } \\
\hline Bean yellow mosaic virus (BYMV), M11 isolate & $\begin{array}{l}\text { BYMV severe strains and Clover } \\
\text { yellow vein virus }\end{array}$ & Vicia faba & Lab & 2009 & [71] \\
\hline $\begin{array}{l}\text { Cowpea aphid-borne mosaic virus (CABMV), } \\
\text { cowpea and passionfruit isolates }\end{array}$ & $\begin{array}{l}\text { various combinations of severe } \\
\text { isolates }\end{array}$ & Canavalia ensiformis, Passiflora edulis & Lab & 2017 & [72] \\
\hline Maize dwarf mosaic virus (MDMV) & $\begin{array}{l}\text { Bermuda grass Southern } \\
\text { mosaic virus (BgSMV) }\end{array}$ & Sorghum (unknown species) & Lab & 2012 & [73] \\
\hline $\begin{array}{l}\text { Papaya ringspot virus (PRSV), PRSV HA 5-1 and } \\
6-1 \text { mutated strains }\end{array}$ & $\begin{array}{c}\text { PRSV-W severe strains } \\
\text { PRSV-W-C, PRSV-W-B, } \\
\text { PRSV-W-P }\end{array}$ & Carica papaya & Field & 1998 & [74] \\
\hline $\begin{array}{l}\text { Papaya ringspot virus (PRSV), PRSV-W-SD } \\
\text { mutated strains C57A, K125D, G317K, P328A }\end{array}$ & Wild type PRSV-W-gfp & Cucumis melo & Lab & 2019 & [75] \\
\hline PRSV-W mild strains PRSV-W-1 and PRSV-W-2 & $\begin{array}{l}\text { PRSV-W severe strains } \\
\text { PRSV-W-C, PRSV-W-B, } \\
\text { PRSV-W-P }\end{array}$ & Cucurbita pepo cv. Caserta and cv. Clarinda & Field & 1998 & [76] \\
\hline Pepper severe mosaic virus (PeSMV), M-1 strain & PeSMV virulent strains & Capsicum cv. XPH 833 and cv. NUN 3364 & Lab & 1988 & [77] \\
\hline Plum pox virus (PPV) mild strains & PPV severe strains & Prunus persica GF305 & Lab & 2008 & [78] \\
\hline $\begin{array}{l}\text { Potato virus Y (PVY) mild strains M-MY10 and } \\
\text { N-NA10 }\end{array}$ & PVY severe isolate NTND6 & Nicotiana tabacum cv. Xanthi & $\mathrm{Lab}$ & 2013 & [79] \\
\hline PVY isolates Li, FrKV2, Wy, Wi, Cou8/03, 47/96 & $\begin{array}{l}\text { various combination of PVY } \\
\text { isolates }\end{array}$ & $\begin{array}{l}\text { Nicotiana tabacum cv. Samsun, S. tuberosum cv } \\
\text { Irga and cv. Satina }\end{array}$ & $\mathrm{Lab}$ & 2018 & [80] \\
\hline Potato virus A (PVA) tobacco strain & PVA potato strains & Nicotiana tabacum cv. Samsun nn & Lab & 2002 & [81] \\
\hline Soybean mosaic virus (SMV), Aa15-M2 strain & SMV severe strains & Glycine max cv. Shin Tambaguro & Lab and field & 1993 & [82] \\
\hline SMV, mosaic strain & SMV mosaic strain & Glycine max, various cultivars & $\mathrm{Lab}$ & 2008 & [83] \\
\hline Turnip mosaic virus, GK strain & YC5 strain & Arabidopsis thaliana & $\mathrm{Lab}$ & 2014 & [84] \\
\hline Vanilla necrosis potyvirus (VNV), mild strains & VNV severe strains & Vanilla fragrans & $\mathrm{Lab}$ & 1999 & [85] \\
\hline $\begin{array}{l}\text { Watermelon mosaic virus (WMV), EM, CL } \\
\text { isolates; W1-9 isolates }\end{array}$ & $\begin{array}{l}\text { WMV, EM, and CL isolates and } \\
\text { WMV severe strains }\end{array}$ & $\begin{array}{l}\text { Cucurbita maxima cv. Hokou Aokawa Kuri, C. } \\
\text { moshata, various cultivars, C. maxima } x \text { C. } \\
\text { moshata, various cultivars, C. pepo, Cucumis melo } \\
\text { cv. various, Citrullus lunatus cv. Kyokuto, } \\
\text { Lagenaria siceraria cv. Shimotsukeshiro }\end{array}$ & $\mathrm{Lab}$ & 1992, 2011 & {$[86,87]$} \\
\hline $\begin{array}{l}\text { Zucchini yellow mosaic virus (ZYMV), WK } \\
\text { isolate }\end{array}$ & ZYMV severe strains & $\begin{array}{l}\text { Curcubita pepo cvs. Elite, Oriental sweet melon, } \\
\text { Cucumis sativus cv. Marketer }\end{array}$ & Lab and field & 1991 & [19] \\
\hline \multicolumn{6}{|l|}{ Rymovirus } \\
\hline $\begin{array}{l}\text { Wheat streak mosaic virus (WSMV), Type and } \\
\text { Sidney } 81 \text { strains }\end{array}$ & $\begin{array}{l}\text { WSMV, Type and Sidney } 81 \\
\text { strains }\end{array}$ & Triticum aestivum $\mathrm{cv}$. Centurk & Lab & 2001 & [88] \\
\hline
\end{tabular}


Table 1. Cont.

\begin{tabular}{|c|c|c|c|c|c|}
\hline Protecting Virus & Challenging Virus & Host Plant & Test Site & Year of Publication & Reference \\
\hline \multicolumn{6}{|l|}{ Tobamovirus } \\
\hline $\begin{array}{l}\text { Cucumber green mottle mosaic virus (CGMMV), } \\
\text { VIROG-43Ms strain }\end{array}$ & $\begin{array}{l}\text { CGMMV, MC- } 1 \text { and MC- } 2 \\
\text { isolates }\end{array}$ & Cucumis sativus var. Kurazh F1 & Lab & 2016 & [89] \\
\hline CGMMV Pk- 47 and Pk-81 & Wild type CGMMV & Cucumis sativus & $\mathrm{Lab}$ & 2010 & [90] \\
\hline Hibiscus latent Singapore virus (HLSV) & Tobacco mosaic virus-U1 & Nicotiana benthamiana & $\mathrm{Lab}$ & 2013 & [91] \\
\hline $\begin{array}{l}\text { Pepper mild mottle virus (PMMoV), isolates } \\
\text { L3-163 }\end{array}$ & Wild type PMMoV isolate & Capsicum annuum, various cultivars & $\mathrm{Lab}$ & 2013 & [92] \\
\hline Tobacco mosaic virus (TMV), 43A & Wild type TMV & Nicotiana benthamiana & Lab & 2019 & [93] \\
\hline TMV, MII-16 strain & $\mathrm{TMV}$, type $\mathrm{O}$ isolate & Solanum lycopersicum cv. Potentate & $\mathrm{Lab}$ & 1977 & [94] \\
\hline TMV mild strain & TMV & Cарscicum аппиит various cultivars & Lab & 1984 & [95] \\
\hline Crucifer TMV, CgYD strain (engineered) & Crucifer TMV, Cg strain & $\begin{array}{l}\text { Arabidopsis thaliana ecotype Col-0 and sde1 } \\
\text { (ecotype C24) }\end{array}$ & Lab & 2003 & [96] \\
\hline Satellite TMV, type 5 and type 6 & Satellite TMV, type 5 and type 6 & Nicotiana tabacum cv. Xanthi nn & $\mathrm{Lab}$ & 1994 & [97] \\
\hline $\begin{array}{l}\text { Tomato mosaic virus (ToMV), } \mathrm{L}_{11} \mathrm{~A} \text {-Fukushima } \\
\text { strain }\end{array}$ & ToMV severe strains & Solanum lycopersicum cv. Momotaro & Field & 2002 & [98] \\
\hline \multicolumn{6}{|l|}{ Tospovirus } \\
\hline $\begin{array}{l}\text { Tomato spotted wilt virus (TSWV), R27G mild } \\
\text { strain }\end{array}$ & TSWV, BL isolate & Datura stramonium $\mathrm{L}$. & Lab & 1992 & [99] \\
\hline
\end{tabular}

${ }^{*}$ Lab $=$ Research laboratory or glasshouse. 


\section{Commercialization of Mild Strain Cross-Protection: Case Study Pepino Mosaic Virus}

Pepino mosaic virus (PepMV), genus Potexvirus, was discovered in the 1970s by Jones, Koenig, and Lesemann [100]. Originally found on pepino (Solanum muricatum) plants in Peru, extensive host range studies showed that not only numerous Solanum species and other members of the Solanaceae family can be infected by PepMV but also artificial infection (albeit not systemic infection) of Tetragonia expansa, a member of the Aizoaceae family and Cucumis sativus, a member of the Cucurbitaceae were possible (although these hosts may not play a major role under natural conditions) [90]. As a potexvirus, PepMV is easily transmitted mechanically but not by common virus vectors such as aphids.

However, for two decades, PepMV lived in the shadows until an outbreak was reported in greenhouse tomatoes in the Netherlands [101]; the first report of natural infection of tomatoes by PepMV. Since then, PepMV has been found in virtually all tomato-producing European countries; the ease of mechanical transmission during handling of tomato crops as well as the use of untreated tomato seeds and the global trade of this high-value crop may also have contributed to the spread of PepMV within Europe and worldwide within a few years; transmission by pollinating bumblebees or soil-borne fungal vectors as well as infested irrigation water may play additional routes of rapid spread of PepMV within greenhouse facilities [66,102-108]. The economic impact of PepMV is immense as fruit symptoms such as marbled, discolored, or open fruits have a lower market value or cannot be sold at all [105,109-111].

Although several attempts were underway to find sources of genetic resistance to PepMV within accessions of tomato and wild relatives, to the best of our knowledge, no PepMV-resistant tomato varieties are yet available [102,103]. In addition, PepMV comprises at least four different genetic groups; different isolates cause different symptoms depending on hosts and these might harbor strains that can overcome potential resistance $[105,109,110,112-122]$. The observation of naturally occurring mild PepMV strains with little or no impact on fruit symptoms and/or yield led to the proposal to use those mild strains for cross-protection purposes [105,123-125]. Moreover, attempts have been carried out to produce "artificial" mild strains for the use as cross-protecting agents $[69,125]$.

In 2015, the European Food Safety Authority (EFSA) concluded that there was no consumer risk in using a natural mild strain, PepMV CH2 isolate 1906 (provided the applied product was free from microbial contaminants) for MSCP, but also identified knowledge gaps in terms of environmental risk assessment or ecotoxicology [126]. Nevertheless, the mild strain was commercialized and licensed in 14 European countries, protecting more than 4500 ha of tomatoes since its introduction [127]. A second mild strain PepMV product VX1 was assessed by EFSA in 2017; in this case, no major risks associated with the application of this mild strain were identified [128]. The commercial product "V10" includes two different mild strains of PepMV, VX1 and VC1, and suppresses symptoms induced by different PepMV strains [129]. A similar approach of combining more than one mild strain to protect tomato crops from a range of PepMV isolates was recently adopted by Agüero and colleagues [68] who tested the ability of two mild isolates of PepMV (Sp-13 and PS5) in various field trials.

It is encouraging to see that MSCP works well in these crops and can hopefully also be applied to other viruses that pose threats to tomato production including the newly emerging tomato brown rugose fruit virus, a tobamovirus with a similar mode of transmission as PepMV that has the potential to severely affect tomato production worldwide [130].

\section{Mechanism(s) of Mild Strain Cross-Protection}

A common explanation of cross-protection is RNA silencing. During RNA silencing, double stranded RNA (dsRNA) produced during viral replication is recognized by Dicer-like (DCL) enzymes and cleaved into small fragments, 21-26 nucleotides long [131,132]. These small nucleotide fragments are called "small-interfering RNAs" (siRNAs) and are able to increase the antiviral RNA silencing response of the host plant by forming an RNA-induced silencing complex (RISC) together with Argonaute proteins. RISC has RNase III activity and degrades RNAs that share sequence identity with the siRNA that was used to form the RISC [131]. By dispersing siRNAs throughout the plant, systemic 
silencing occurs whereby viral silencing is induced in parts of the plant that had no previous viral contact. In this way RNAs that are similar in sequence to the RNA that first triggered the silencing response are broken down in all parts of the plant during systemic silencing. The sequence fidelity of this model may explain why cross-protection only works between closely related viruses and why genetically divergent viruses are able to evade recognition by RISC. In addition, the Argonaute proteins have also been implicated in translational repression of viral RNAs, induced by a combination of host resistance genes and viral elicitors [133,134]; whether this or degradation underlies MCSP requires further research.

RNA silencing by itself is not able to explain the mechanism of cross-protection fully. In a study done by Ziebell, Payne, Berry, Walsh, and Carr [135] a 2b silencing suppressor protein deletion mutant of cucumber mosaic virus (CMV) was unable to induce the strong systemic silencing signal expected of a virus lacking an RNA silencing suppressor, although it did provide limited protection against its parental strain (Fny-CMV) in Nicotiana tabacum and Nicotiana benthamiana. Interestingly, both strains appeared to be highly localized on a cellular level, with the two viruses occupying different cells, a phenomenon that has also been observed for other virus systems [136]. The authors suggested that cross-protection occurs either via very highly localized RNA silencing or via the competition between protective and challenge strains for host cells and resources. Furthermore, the observed protection against the parental Fny-CMV strain also occurred in silencing-deficient Arabidopsis thaliana plants, casting more doubt that RNA silencing was involved with at least this virus system [137]. Another study by Takeshita, Shigemune, Kikuhara, Furuya, and Takanami [138] supported the notion that RNA silencing by itself is unable to explain the phenomenon of cross-protection fully. The authors showed that different strains of CMV can spatially exclude each other from tissues in cowpea plants.

An alternative model explaining cross-protection without RNA silencing involves the protective strain preventing the challenge strain from uncoating upon entering the plant cell. The coat protein from the protective mild strain may recoat the challenge strain and prevent its replication [139], a proposal refuted based on effective protective strains of tobacco mosaic virus that produce no coat protein [140], or prevent uncoating by an undefined mechanism.

Superinfection-exclusion was proposed as the mechanism by which CTV cross-protection occurs [23], where it was observed that isolates are unable to superinfect a plant that has been pre-inoculated with an isolate of the same genotype. Homology between the pre- and superinfecting isolates is key, suggesting a genetic component is involved [141]. However, further research into this phenomenon found that the relative fitness between the protective and challenge isolates can determine whether superinfection can occur, thus a "weak" protective isolate can be superinfected by a more "adapted" challenge isolate [142]. Furthermore, the exclusion phenomenon was not uniform throughout the plant, and superinfection occurred between even near-identical isolates in the roots and lower stem of a plant [142].

In citrus at least, extant protective isolates such as GSMS-12 and Pera/IAC are populations, mixtures of different genotypes [143,144], suggesting another potential mechanism, the interaction of different isolates to alter fitness of one or more components of the population. It has been demonstrated that virus-virus interaction can alter isolate fitness, titer, and tropism through complementation or antagonism [33,145,146], and further research has found that these interactions can also be disrupted, and/or target suppressed genotypes [146], (Harper unpublished). It may be that a protective mixture is able to incorporate a pathogenic challenge isolate into the population, and reduce its fitness such that it cannot accumulate or express to a level necessary for pathogenesis.

The cross-protection phenomenon may not have a simple or single explanation. While some studied MSCP strains protect against infection with challenge isolates by triggering RNA silencing, others do not [10]. In some cases a specific viral protein is required for cross-protection, as is the case in the CTV pathosystem where p33 is required for cross-protection [147]. These experiments demonstrate that although cross-protection has been known to be an effective strategy in protecting plants from 
severe symptom development for almost a century, the exact mechanism of cross-protection, and therefore its efficacy constraints, remains obscure.

\section{The Mild Strain Cross-Protection Era}

Cross-protection as a disease management strategy can be very successful, as proven by the management of CTV or PepMV. Eradication of CTV by removing infected trees has proven unsuccessful, as the virus spreads quicker than infected trees can be identified and subsequently removed [10]. Using cultural practices and maintaining the populations of insect vectors at low levels to reduce pathogenic virus spread may be sufficient, however, these methods are often inadequate in lowering disease incidence.

For traditional breeding or cis-genics these are seldom the required genetic sources of resistance available within a cultivar, e.g., zucchini squash does not harbor sources of resistance to papaya ringspot virus type W (PRSV-W) within its genome [76]. While other management strategies, like genetically engineered resistance may be more effective in preventing disease incidence and spread, cross-protection offers a non-genetically modified (GMO) option for disease control that is more likely to be accepted by the public.

Societal and environmental pressures demand high quality and resilient cropping plants and produce with the use of low or no synthetic chemical inputs. Pathogenic viruses result in significant losses in crop production and crop quality but these are increasingly managed by MSCP which is both environmentally safe and socially friendly. Since MSCP is dependent on host and virus strains, an effort in finding local mild strains has to be made; any one mild strain cannot be used for the protection of cultivars grown in different locations. New technologies are converging to support the discovery and mechanism(s) of MSCP strains thereby accelerating the popularity of their use. However, without bioinformatic predictions of host range or pathogenicity the major barrier to the use of MSCP strains is in demonstrating their efficacy. Once efficacy is secured, MSCP proffers effective and sustainable protection against pathogenic viruses of crop plants across a range of production environments. The analysis of the societal and environmental benefits from the application of MSCP technology may provide impetus to further accelerate its use and, perhaps, assist in clarifying its underlying mechanism(s).

Author Contributions: K.P. wrote an original draft under the supervision of R.M.M., K.M.C., and S.J.H. Specific sections were written or updated by R.M.M. (societal and environmental pressures), H.Z. (Table 1 and PepMV case study), S.J.H. (MSCP discovery and mechanisms). The manuscript was substantially revised and edited by K.M.C.

Funding: The authors would like to thank New Zealand Citrus Growers Incorporated for supporting K.P., a German-New Zealand cooperation grant from the Federal Office for Agriculture and Food, Germany and The Royal Society of New Zealand for supporting H.Z. and R.M.M., and the Virus-Vector project that is part of The New Zealand Institute for Plant and Food Research Limited Strategic Science Investment Fund research programme, funded by the Ministry for Business, Innovation \& Employment for supporting K.C. and R.M.M. The sponsors had no role in the design, execution, interpretation, or writing of this review.

Acknowledgments: We thank Nicholas Amponsah and Daniel Cohen for providing helpful comments prior to manuscript submission.

Conflicts of Interest: The authors have no conflicts of interest.

\section{References}

1. Heimpel, G.E.; Yang, Y.; Hill, J.D.; Ragsdale, D.W. Environmental consequences of invasive species: Greenhouse gas emissions of insecticide use and the role of biological control in reducing emissions. PLoS ONE 2013, 8, e72293. [CrossRef] [PubMed]

2. IPCC (Intergovernmental Panel on Climate Change). Climate Change 2014: Mitigation of Climate Change. Contribution of Working Group III to the Fifth Assessment Report of the Intergovernmental Panel on Climate Change; Cambridge University Press: New York, NY, USA, 2014. 
3. Smith, P.; Haberl, H.; Popp, A.; Erb, K.H.; Lauk, C.; Harper, R.; Tubiello, F.N.; Pinto, A.D.; Jafari, M.; Sohi, S.; et al. How much land-based greenhouse gas mitigation can be achieved without compromising food security and environmental goals? Global Change Biol. 2013, 19, 2285-2302. [CrossRef] [PubMed]

4. Springmann, M.; Clark, M.; Mason-D'Croz, D.; Wiebe, K.; Bodirsky, B.L.; Lassaletta, L.; de Vries, W.; Vermeulen, S.J.; Herrero, M.; Carlson, K.M.; et al. Options for keeping the food system within environmental limits. Nature 2018, 562, 519-525. [CrossRef] [PubMed]

5. Shah, F.; Wu, W. Soil and crop management strategies to ensure higher crop productivity within sustainable environments. Sustainability 2019, 11, 1485. [CrossRef]

6. Rockstrom, J.; Williams, J.; Daily, G.; Noble, A.; Matthews, N.; Gordon, L.; Wetterstrand, H.; DeClerck, F.; Shah, M.; Steduto, P.; et al. Sustainable intensification of agriculture for human prosperity and global sustainability. Ambio 2017, 46, 4-17. [CrossRef] [PubMed]

7. FAO (Food and Agriculture Organization). Building a Common Vision for Sustainable Food and Agriculture: Principles and Approaches; Food and Agriculture Organization of the United Nations: Rome, Italy, 2014.

8. Anderson, P.K.; Cunningham, A.A.; Patel, N.G.; Morales, F.J.; Epstein, P.R.; Daszak, P. Emerging infectious diseases of plants: Pathogen pollution, climate change and agrotechnology drivers. Trends Ecol. Evol. 2004, 19, 535-544. [CrossRef] [PubMed]

9. About the Sustainable Development Goals-United Nations Sustainable Development. Available online: https://www.un.org/sustainabledevelopment/sustainable-development-goals/ (accessed on 03 June 2019).

10. Ziebell, H.; Carr, J.P. Cross-protection: A century of mystery. Adv. Virus Res. 2010, 76, 211-264. [PubMed]

11. Foley, J.A.; Ramankutty, N.; Brauman, K.A.; Cassidy, E.S.; Gerber, J.S.; Johnston, M.; Mueller, N.D.; O'Connell, C.; Ray, D.K.; West, P.C.; et al. Solutions for a cultivated planet. Nature 2011, 478, 337-342. [CrossRef]

12. Van Bueren, E.T.L.; Struik, P.C.; van Eekeren, N.; Nuijten, E. Towards resilience through systems-based plant breeding. A review. Agron. Sustain. Dev. 2018, 38, 42. [CrossRef]

13. Jijelava, D.; Vanclay, F. How a large project was halted by the lack of a social licence to operate: Testing the applicability of the Thomson and Boutilier model. Environ. Impact Asses. 2018, 73, 31-40. [CrossRef]

14. Ziebell, H.; MacDiarmid, R. Prospects for engineering and improvement of cross-protective virus strains. Curr. Opin. Virol. 2017, 26, 8-14. [CrossRef] [PubMed]

15. Bar-Joseph, M. Cross protection incompleteness: A possible cause for natural spread of citrus tristeza virus after a prolonged period in Israel. Phytopathology 1978, 68, 1110-1111. [CrossRef]

16. Costa, A.S.; Muller, G.W. Tristeza control by cross protection: A U.S.-Brazil cooperative success. Plant. Dis. 1980, 64, 538-541. [CrossRef]

17. Powell, C.A.; Pelosi, R.R.; Rundell, P.A.; Cohen, M. Breakdown of crossprotection of grapefruit from decline-inducing isolates of citrus tristeza virus following introduction of the brown citrus aphid. Plant Dis. 2003, 87, 1116-1118. [CrossRef] [PubMed]

18. Rezende, J.A.M.; Sherwood, J.L. Breakdown of cross protection between strains of tobacco mosaic virus due to susceptibility of dark green areas to superinfection. Phytopathology 1991, 81, 1490-1496. [CrossRef]

19. Wang, H.L.; Gonsalves, D.; Provvidenti, R.; Lecoq, H.L. Effectiveness of cross-protection by a mild strain of zucchini yellow mosaic-virus in cucumber, melon, and squash. Plant Dis. 1991, 75, 203-207. [CrossRef]

20. Wang, H.L.; Yeh, S.-D.; Chiu, R.J.; Gonsalves, D. Effectiveness of cross-protection by mild mutants of papaya ringspot virus for control of ringspot disease of papaya in Taiwan. Plant Dis. 1987, 71, 491-497. [CrossRef]

21. Zhou, C.Y.; Broadbent, P.; Hailstones, D.L.; Bowyer, J.; Connor, R. Movement and Titre of Citrus Tristeza Virus (pre immunizing isolate PB61) within Seedlings and Field Trees, 15th Conference of the International Organization of Citrus Virologists; Duran Vila, N., Milne, R.G., da Graca, J.V., Eds.; University of California: Riverside, CA, USA, 2002; pp. 39-47.

22. Koizumi, M.; Sasaki, A. Protection Phenomena against Tristeza in Trees pre-Inoculated with vein-Enation Virus, Proceedings of the 8th International Organization of Citrus Virologists, Riverside; IOCV: Riverside, CA, USA, 1980; pp. $48-50$.

23. Folimonova, S.Y. Developing an understanding of cross-protection by citrus tristeza virus. Front. Microbiol. 2013, 4, 76. [CrossRef]

24. Jridi, C.; Martin, J.-F.; Marie-Jeanne, V.; Labonne, G.; Blanc, S. Distinct viral populations differentiate and evolve independently in a single perennial host plant. J. Virol. 2006, 80, 2349-2357. [CrossRef] 
25. Müller, G.W.; Rezende, J.A. Preimmunization: Applications and perspectives in virus disease control. Diseases of Fruits and Vegetables Volume I 2004, 1, 361-395.

26. Baba, V.Y.; Giampani, J.S.; Tazima, Z.H.; Yada, I.F.U.; Paccola-Meirelles, L.D.; Leite, R.P. Agronomic performance of pera and related sweet orange accessions naturally infected with citrus tristeza virus in Northern Parana State, Brazil. Trop. Plant Pathol. 2014, 39, 442-448. [CrossRef]

27. Salibe, A.A.; Souza, A.A.; Targon, M.L.P.N.; Müller, G.W.; Coletta Filho, H.D.; Machado, M.A. Selection of a Mild Sub-Isolate of Citrus Tristeza Virus for Preimmunization of pera Sweet Orange, 15th Conference of the International Organization of Citrus Virologists; Duran Vila, N., Milne, R.G., da Graca, J.V., Eds.; University of California: Riverside, CA, USA, 2002; pp. 348-351.

28. Yeh, S.D.; Cheng, Y.H. Use of resistant Cucumis metuliferus for selection of nitrous-acid induced attenuated strains of papaya ringspot virus. Phytopathology 1989, 79, 1257-1261. [CrossRef]

29. Desjardins, P.R.; Wallace, J.M.; Wollman, E.S.H.; Drake, R.J. A separation of virus strains from a tristeza-seedling-yellows complex by heat treatment of infected lime seedlings. Citrus Virus Dis. 1959, 91-95.

30. Cook, G.; van Vuuren, S.P.; Breytenbach, J.H.J.; Burger, J.T.; Maree, H.J. Expanded strain-specific RT-PCR assay for differential detection of currently known citrus tristeza virus strains: A useful screening tool. J. Phytopathology 2016, 164, 847-851. [CrossRef]

31. Kamitani, M.; Nagano, A.J.; Honjo, M.N.; Kudoh, H.; Kummerli, R. RNAseq reveals virus-virus and virus-plant interactions in nature. Fems Microbiol. Ecol. 2016, 92. [CrossRef] [PubMed]

32. Zablocki, O.; Pietersen, G. Characterization of a novel citrus tristeza virus genotype within three cross-protecting source GFMS12 sub-isolates in South Africa by means of Illumina sequencing. Arch. Virol. 2014, 159, 2133-2139. [CrossRef]

33. Harper, S.J.; Cowell, S.J.; Robertson, C.J.; Dawson, W.O. Differential tropism in roots and shoots infected by citrus tristeza virus. Virology 2014, 460, 91-99. [CrossRef]

34. MacDiarmid, R.M.; Rodoni, B.; Melcher, U.; Ochoa-Corona, F.; Roossinck, M. Biosecurity implications of new technology and discovery in plant virus research. Plos Pathog. 2013, 9, e1003337. [CrossRef]

35. McKinney, H.H. Mosaic diseases in the Canary Islands, West Africa and Gibraltar. J. Agric. Res. 1929, 39, 557-578.

36. Salaman, R.N. Protective inoculation against a plant virus. Nature 1933, 131, 468. [CrossRef]

37. Salaman, R.N.; Smith, K.M.; MacClement, W.D.; Bawden, F.C.; Bernal, J.D.; McFarlane, A.S.; Findlay, G.M.; Watson, M.A.; Murphy, P.A.; Elford, W.J. A discussion on new aspects of virus disease. Proc. R. Soc. Lond. B 1938, 125, 291-310.

38. Thung, T.H. Smetstof en plantecel bij enkele virusziekten van de Tabaksplant. Rev. Appl. Mycol. 1932, 11, 750-751.

39. Kudela, O.; Gallo, J. Characterization of the alfalfa mosaic virus strain t6. Acta. Virol. 1995, 39, $131-135$. [PubMed]

40. Ameyaw, G.A.; Domfeh, O.; Dzahini-Obiatey, H.; Ollennu, L.A.A.; Owusu, G.K. Appraisal of cocoa swollen shoot virus (CSSV) mild isolates for cross-protection of cocoa against severe strains in Ghana. Plant Dis. 2016, 100, 810-815. [CrossRef] [PubMed]

41. Chen, Y.J.; Zhang, J.; Liu, J.; Deng, X.G.; Zhang, P.; Zhu, T.; Chen, L.J.; Bao, W.K.; Xi, D.H.; Lin, H.H. The capsid protein p38 of turnip crinkle virus is associated with the suppression of cucumber mosaic virus in Arabidopsis thaliana co-infected with cucumber mosaic virus and turnip crinkle virus. Virology 2014, 462, 71-80. [CrossRef] [PubMed]

42. Zhang, X.S.; Melcher, U. Competition between isolates and variants of cauliflower mosaic-virus in infected turnip plants. J. Gen. Virol. 1989, 70, 3427-3437. [CrossRef]

43. Vidalakis, G.; Garnsey, S.M.; Bash, J.A.; Greer, G.D.; Gumpf, D.J. Efficacy of bioindexing for graft-transmissible citrus pathogens in mixed infections. Plant. Dis. 2004, 88, 1328-1334. [CrossRef]

44. Zanutto, C.A.; Corazza, M.J.; Nunes, W.M.D.; Muller, G.W. Evaluation of the protective capacity of new mild citrus tristeza virus (CTV) isolates selected for a preimmunization program. Sci. Agr. 2013, 70, 116-124. [CrossRef]

45. Da Graca, J.V.; van Vuuren, S.P. Managing citrus tristeza virus losses using cross-protection. In Citrus Tristeza Virus Complex and Tristeza Diseases; Karasev, A.V., Hilf, M.E., Eds.; The American Phytopathological Society (APS): St. Paul, MN, USA, 2010; pp. 247-260. 
46. Read, D.A.; Pietersen, G. Genotypic diversity of citrus tristeza virus within red grapefruit, in a field trial site in South Africa. Eur. J. Plant Pathol. 2015, 142, 531-545. [CrossRef]

47. Bederski, K.; Roistacher, C.N.; Silvestre, O.P.; Müller, G.W. Long-Term Cross-Protection of Severe Stem Pitting Citrus Tristeza Virus in Peru, 17th Conference of the International Organization of Citrus Virologists, Riverside, CA, USA; IOCV: Riverside, CA, USA, 2010; pp. 67-79.

48. Dodds, J.A.; Lee, S.Q.; Tiffany, M. Cross protection between strains of cucumber mosaic-virus-Effect of host and type of inoculum on accumulation of virions and double-stranded-RNA of the challenge strain. Virology 1985, 144, 301-309. [CrossRef]

49. Gallitelli, D.; Vovlas, C.; Martelli, G.; Montasser, M.S.; Tousignant, M.E.; Kaper, J.M. Satellite-mediated protection of tomato against cucumber mosaic-virus: II. Field-test under natural epidemic conditions in Southern Italy. Plant Dis. 1991, 75, 93-95. [CrossRef]

50. Montasser, M.S.; Tousignant, M.E.; Kaper, J.M. Viral satellite RNAs for the prevention of cucumber mosaic virus (CMV) disease in field-grown pepper and melon plants. Plant Dis. 1998, 82, 1298-1303. [CrossRef] [PubMed]

51. Sayama, H.; Sato, T.; Kominato, M.; Natsuaki, T.; Kaper, J.M. Field testing of a satellite-containing attenuated strain of cucumber mosaic-virus for tomato protection in Japan. Phytopathology 1993, 83, 405-410. [CrossRef]

52. Kosaka, Y.; Fukunishi, T. Multiple inoculation with three attenuated viruses for the control of cucumber virus disease. Plant Dis. 1997, 81, 733-738. [CrossRef] [PubMed]

53. Kuti, J.O.; Moline, H.E. Effects of inoculation with a mild strain of tomato aspermy virus on the growth and yield of tomatoes and the potential for cross-protection. J. Phytopathol. 1986, 115, 56-60. [CrossRef]

54. Mahmood, T.; Rush, C.M. Evidence of cross-protection between beet soilborne mosaic virus and beet necrotic yellow vein virus in sugar beet. Plant Dis. 1999, 83, 521-526. [CrossRef] [PubMed]

55. Grupa, A.; Syller, J. Cross-protection between a naturally occurring mild isolate of potato virus $\mathrm{m}$ (PVM) and a more virulent isolate in Datura metel plants. J. Phytopathol. 2016, 164, 69-73. [CrossRef]

56. Owor, B.; Legg, J.P.; Okao-Okuja, G.; Obonyo, R.; Kyamanywa, S.; Ogenga-Latigo, M.W. Field studies of cross-protection with cassava mosaic geminiviruses in Uganda. J. Phytopathol. 2004, 152, 243-249. [CrossRef]

57. Reddy, R.V.C.; Dong, W.B.; Njock, T.; Rey, M.E.C.; Fondong, V.N. Molecular interaction between two cassava geminiviruses exhibiting cross-protection. Virus Res. 2012, 163, 169-177. [CrossRef] [PubMed]

58. Chamberlain, E.E.; Atkinson, J.D.; Hunter, J.A. Cross-protection between strains of apple mosaic virus. New Zealand J. Agric. Res. 1964, 7, 480-490. [CrossRef]

59. Jedlinski, H.; Brown, C.M. Cross protection and mutual exclusion by three strains of barley yellow dwarf virus in Avena sativa L. Virology 1965, 26, 613-621. [CrossRef]

60. Wen, F.; Lister, R.M.; Fattouh, F.A. Cross-protection among strains of barley yellow dwarf virus. J. Gen. Virol. 1991, 72, 791-799. [CrossRef] [PubMed]

61. Webb, R.E. A new strain of potato leaf roll virus. Am. Potato J. 1955, 32, 173-179. [CrossRef]

62. Kondo, T.; Kogawa, K.; Ito, K. Evaluation of cross-protection by an attenuated strain of Chinese yam necrotic mosaic virus in Chinese yam. J. Gen. Plant. Pathol. 2015, 81, 42-48. [CrossRef]

63. Komar, V.; Vigne, E.; Demangeat, G.; Lemaire, O.; Fuchs, M. Cross-protection as control strategy against grapevine fanleaf virus in naturally infected vineyards. Plant. Dis. 2008, 92, 1689-1694. [CrossRef] [PubMed]

64. Legin, R.; Bass, P.; Etienne, L.; Fuchs, M. Selection of mild virus-strains of fanleaf degeneration by comparative field performance of infected grapevines. Vitis 1993, 32, 103-110.

65. Bitterlin, M.W.; Gonsalves, D. Serological grouping of tomato ringspot virus isolates-Implications for diagnosis and cross-protection. Phytopathology 1988, 78, 278-285. [CrossRef]

66. Hanssen, I.M.; Gutiérrez-Aguirre, I.; Paeleman, A.; Goen, K.; Wittemans, L.; Lievens, B.; Vanachter, A.C.R.C.; Ravnikar, M.; Thomma, B.P.H.J. Cross-protection or enhanced symptom display in greenhouse tomato co-infected with different pepino mosaic virus isolates. Plant. Pathol. 2010, 59, 13-21. [CrossRef]

67. Vermunt, A.M.W.; Kaarsemaker, R.C. Multi-genotype cross-protection against pepino mosaic virus in tomato. Crop. Prot. 2017, 96, 116-122. [CrossRef]

68. Agüero, J.; Gómez-Aix, C.; Sempere, R.N.; García-Villalba, J.; García-Núñez, J.; Hernando, Y.; Aranda, M.A. Stable and broad spectrum cross-protection against pepino mosaic virus attained by mixed infection. Front. Plant Sci. 2018, 9, 1810. [CrossRef] 
69. Chewachong, G.M.; Miller, S.A.; Blakeslee, J.J.; Francis, D.M.; Morris, T.J.; Qu, F. Generation of an attenuated, cross-protective pepino mosaic virus variant through alignment-guided mutagenesis of the viral capsid protein. Phytopathology 2015, 105, 126-134. [CrossRef] [PubMed]

70. Cong, Q.Q.; Wang, Y.; Liu, J.; Lan, Y.F.; Guo, Z.K.; Yang, J.G.; Li, X.D.; Tian, Y.P. Evaluation of potato virus X mild mutants for cross-protection against severe infection in China. Virol. J. 2019, 16. [CrossRef] [PubMed]

71. Nakazono-Nagaoka, E.; Takahashi, T.; Shimizu, T.; Kosaka, Y.; Natsuaki, T.; Omura, T.; Sasaya, T. Cross-protection against bean yellow mosaic virus (BYMV) and clover yellow vein virus by attenuated BYMV isolate M11. Phytopathology 2009, 99, 251-257. [CrossRef] [PubMed]

72. Maia, L.M.; Lima, J.A.d.A.; do Nascimento, A.K.Q.; Rabelo Filho, F.d.A.C. Biological differences and unilateral cross-protection between biotypes of Cowpea aphid-borne mosaic virus. Rev. Ciência Agronômica 2017, 48, 310-317. [CrossRef]

73. Zakeri, A.; Masumi, M.; Nejad, S.N.; Ghahramani, T.; Izadpanah, K. Cross protection between maize dwarf mosaic virus and Bermuda grass southern mosaic virus. Iran. J. Plant Pathol. 2012, 48, 51.

74. Gonsalves, D. Control of papaya ringspot virus in papaya: A case study. Annu. Rev. Phytopathol. 1998, 36, 415-437. [CrossRef]

75. Huang, X.D.; Fang, L.; Gu, Q.S.; Tian, Y.P.; Geng, C.; Li, X.D. Cross protection against the watermelon strain of papaya ringspot virus through modification of viral RNA silencing suppressor. Virus Res. 2019, 265, 166-171. [CrossRef]

76. Rezende, J.A.M.; Pacheco, D.A. Control of papaya ringspot virus-type $w$ in zucchini squash by cross-protection in Brazil. Plant Dis. 1998, 82, 171-175. [CrossRef]

77. Tanzi, M.; Betti, L.; Canova, A. Protection of pepper crops under glass against PepMV artificial infection with the mild mutant M-1: Analysis of its influence on growth and yield. Adv. Hortic. Sci. 1988, 2, 19-22.

78. Ravelonandro, M.; Briard, P.; Glasa, M.; Adam, S. The ability of a mild isolate of plum pox virus to cross-protect against sharka virus. In Proceedings of the Twentieth International Symposium on Virus and Virus-Like Diseases of Temperate Fruit Crops—Fruit Tree Diseases, Antalya, Turkey, 22 May 2006; pp. 281-286. [CrossRef]

79. Ogawa, T.; Nakamura, S.; Sayama, M.; Ohshima, K. Attenuated mutants of potato virus Y necrotic strain produced by nitrous acid treatment and mutagenesis-in-tissue culture methods. Eur. J. Plant. Pathol. 2013, 135, 745-760. [CrossRef]

80. Grupa, A.; Otulak-Koziel, K.; Syller, J. Serological, molecular and immunofluorescent evidence for interference competition between isolates of potato virus Y. Plant Pathol. 2018, 67, 1997-2012. [CrossRef]

81. Valkonen, J.P.T.; Rajamaki, M.L.; Kekarainen, T. Mapping of viral genomic regions important in cross-protection between strains of a potyvirus. Mol. Plant Microbe In. 2002, 15, 683-692. [CrossRef] [PubMed]

82. Kosaka, Y.; Fukunishi, T. Attenuated isolates of soybean mosaic-virus derived at a low-temperature. Plant Dis. 1993, 77, 882-886. [CrossRef]

83. Shi, A.; Chen, P.; Gergerich, R.; Hou, A.; Zhang, B. Interaction between two strains of soybean mosaic virus in soybean. Can. J. Plant Pathol. 2008, 30, 486-491. [CrossRef]

84. Kung, Y.J.; Lin, P.C.; Yeh, S.D.; Hong, S.F.; Chua, N.H.; Liu, L.Y.; Lin, C.P.; Huang, Y.H.; Wu, H.W.; Chen, C.C.; et al. Genetic analyses of the FRNK motif function of turnip mosaic virus uncover multiple and potentially interactive pathways of cross-protection. Mol. Plant Microbe In. 2014, 27, 944-955. [CrossRef] [PubMed]

85. Pearson, M.N.; Keshaw, S.; Gupta, D. Effects of two naturally occurring mild potyviruses on the symptom expression of vanilla necrosis potyvirus in Vanilla fragrans. New Zeal. J. Crop. Hort. 1999, 27, 325-330. [CrossRef]

86. Kameya-Iwaki, M.; Tochihara, H.; Hanada, K.; Torigoe, H. Attenuated isolate of watermelon mosaic virus (WMV-2) and its cross-protection against virulent isolate. Jpn. J. Phytopathol. 1992, 58, 491-494. [CrossRef]

87. Lecoq, H.; Fabre, F.; Joannon, B.; Wipf-Scheibel, C.; Chandeysson, C.; Schoeny, A.; Desbiez, C. Search for factors involved in the rapid shift in watermelon mosaic virus (WMV) populations in South-Eastern France. Virus Res. 2011, 159, 115-123. [CrossRef] [PubMed]

88. Hall, J.S.; French, R.; Hein, G.L.; Morris, T.J.; Stenger, D.C. Three distinct mechanisms facilitate genetic isolation of sympatric wheat streak mosaic virus lineages. Virology 2001, 282, 230-236. [CrossRef] [PubMed] 
89. Slavokhotova, A.A.; Istomina, E.A.; Andreeva, E.N.; Korostyleva, T.V.; Pukhalskij, V.A.; Shijan, A.N.; Odintsova, T.I. An attenuated strain of cucumber green mottle mosaic virus as a biological control agent against pathogenic viral strains. Am. J. Plant Sci. 2016, 7, 724-732. [CrossRef]

90. Ali, A.; Ahmad, M.; Nishigawa, H.; Natsuaki, T. Evaluation of low temperature induced mutants of cucumber green mottle mosaic virus for cross-protection in cucurbits. J. Plant Pathol. Microbiol. 2010, S3. [CrossRef]

91. Wen, Y.; Lim, G.X.Y.; Wong, S.M. Profiling of genes related to cross-protection and competition for NbTOM1 by HLSV and TMV. PLoS ONE 2013, 8, e73725. [CrossRef] [PubMed]

92. Ogai, R.; Kanda-Hojo, A.; Tsuda, S. An attenuated isolate of pepper mild mottle virus for cross-protection of cultivated green pepper (Capsicum annuum 1.) carrying the 13 resistance gene. Crop. Prot. 2013, 54, 29-34. [CrossRef]

93. Das, P.P.; Chua, G.M.; Lin, Q.S.; Wong, S.M. Itraq-based analysis of leaf proteome identifies important proteins in secondary metabolite biosynthesis and defence pathways crucial to cross-protection against TMV. J. Proteomics 2019, 196, 42-56. [CrossRef] [PubMed]

94. Cassells, A.C.; Herrick, C.C. Cross protection between mild and severe strains of tobacco mosaic-virus in doubly inoculated tomato plants. Virology 1977, 78, 253-260. [CrossRef]

95. Goto, T.; Iizuka, N.; Komochi, S. Selection and utilization of an attenuated isolate of pepper strain of tobacco mosaic virus. Jpn. J. Phytopathol. 1984, 50, 221-228. [CrossRef]

96. Kurihara, Y.; Watanabe, Y. Cross-protection in Arabidopsis against crucifer tobamovirus cg by an attenuated strain of the virus. Mol. Plant. Pathol. 2003, 4, 259-269. [CrossRef] [PubMed]

97. Kurath, G.; Dodds, J.A. Satellite tobacco mosaic virus sequence variants with only five nucleotide differences can interfere with each other in a cross-protection-like phenomenon in plants. Virology 1994, 202, 1065-1069. [CrossRef] [PubMed]

98. Matsumoto, T.; Nara, Y.; Furuya, H.; Takahashi, H.; Tairako, K.; Yamamoto, H. Characteristics for practical use of attenuated isolated L11A-Fukushima of Tomato mosaic virus. J. Gen. Plant. Path. 2002, 68, 382-384. [CrossRef]

99. Wang, M.; Gonsalves, D. Artificial induction and evaluation of a mild isolate of tomato spotted wilt virus. J. Phytopathol. 1992, 135, 233-244. [CrossRef]

100. Jones, R.A.C.; Koenig, R.; Lesemann, D.E. Pepino mosaic virus, a new potexvirus from pepino (Solanum muricatum). Ann. Appl. Biol. 1980, 94, 61-68. [CrossRef]

101. van der Vlugt, R.A.A.; Stijger, C.C.M.M.; Verhoeven, J.T.J.; Lesemann, D.-E. First report of pepino mosaic virus on tomato. Plant Dis. 2000, 84, 103. [CrossRef] [PubMed]

102. Alfaro-Fernández, A.; Del Carmen Córdoba-Sellés, M.; Herrera-Vásquez, J.Á.; Cebrián, M.d.C.; Jordá, C. Transmission of pepino mosaic virus by the fungal vector olpidium virulentus. J. Phytopathol. 2010, 158, 217-226. [CrossRef]

103. Córdoba-Sellés, M.d.C.; García-Rández, A.; Alfaro-Fernández, A.; Jordá-Gutiérrez, C. Seed transmission of pepino mosaic virus and efficacy of tomato seed disinfection treatments. Plant Dis. 2007, 91, 1250-1254. [CrossRef]

104. Hanssen, I.M.; Mumford, R.; Blystad, D.R.; Cortez, I.; Hasiow-Jaroszewska, B.; Hristova, D.; Pagan, I.; Pereira, A.M.; Peters, J.; Pospieszny, H.; et al. Seed transmission of pepino mosaic virus in tomato. Eur. J. Plant Pathol. 2010, 126, 145-152. [CrossRef]

105. Hanssen, I.M.; Thomma, B.P.H.J. Pepino mosaic virus: A successful pathogen that rapidly evolved from emerging to endemic in tomato crops. Mol. Plant Pathol. 2010, 11, 179-189. [CrossRef] [PubMed]

106. Lacasa, A.; Guerrero, M.M.; Hita, I.; Martínez, M.A.; Jordá, C.; Bielza, P.; Contreras, A.; Alcázar, A.C. Implicaciones de los abejorros (bombus spp.) en la dispersión del virus del mosaico del pepino dulce (pepino mosaic virus) en cultivos de tomate. Bol San Veg Plagas 2003, 29, 393-403.

107. Ling, K.S. Pepino mosaic virus on tomato seed: Virus location and mechanical transmission. Plant Dis. 2008, 92, 1701-1705. [CrossRef]

108. Schwarz, D.; Beuch, U.; Bandte, M.; Fakhro, A.; Buttner, C.; Obermeier, C. Spread and interaction of pepino mosaic virus (PepMV) and Pythium aphanidermatum in a closed nutrient solution recirculation system: Effects on tomato growth and yield. Plant Pathol. 2010, 59, 443-452. [CrossRef]

109. Hanssen, I.M.; Paeleman, A.; Van Bergen, L.; Vandewoestijne, E.; Wittemans, L.; Goen, K.; Vanachter, A.C.R.C.; Thomma, B.P.H.J. Survey on symptom expression and damage caused by pepino mosaic virus in commercial tomato production in Belgium. Int. Symp. Tomato Dis. 2009, 808, 185-192. [CrossRef] 
110. Hanssen, I.M.; Paeleman, A.; Vandewoestijne, E.; Van Bergen, L.; Bragard, C.; Lievens, B.; Vanachter, A.C.R.C.; Thomma, B.P.H.J. Pepino mosaic virus isolates and differential symptomatology in tomato. Plant Pathol. 2009, 58, 450-460. [CrossRef]

111. Spence, N.J.; Basham, J.; Mumford, R.A.; Hayman, G.; Edmondson, R.; Jones, D.R. Effect of pepino mosaic virus on the yield and quality of glasshouse-grown tomatoes in the UK. Plant Pathol. 2006, 55, 595-606. [CrossRef]

112. Ling, K.S.; Scott, J.W. Sources of resistance to pepino mosaic virus in tomato accessions. Plant Dis. 2007, 91, 749-753. [CrossRef] [PubMed]

113. Soler, S.; Lopez, C.; Prohens, J.; Nuez, F. New sources of resistance to PepMV in tomato. J. Plant Dis. Protect. 2011, 118, 149-155. [CrossRef]

114. Hanssen, I.M.; Paeleman, A.; Wittemans, L.; Goen, K.; Lievens, B.; Bragard, C.; Vanachter, A.C.R.C.; Thomma, B.P.H.J. Genetic characterization of pepino mosaic virus isolates from Belgian greenhouse tomatoes reveals genetic recombination. Eur. J. Plant Pathol. 2008, 121, 131-146. [CrossRef]

115. Hanssen, I.M.; van Esse, H.P.; Ballester, A.R.; Hogewoning, S.W.; Parra, N.O.; Paeleman, A.; Lievens, B.; Bovy, A.G.; Thomma, B.P.H.J. Differential tomato transcriptomic responses induced by pepino mosaic virus isolates with differential aggressiveness. Plant Physiol. 2011, 156, 301-318. [CrossRef] [PubMed]

116. Hasiow-Jaroszewska, B.; Borodynko, N.; Jackowiak, P.; Figlerowicz, M.; Pospieszny, H. Single mutation converts mild pathotype of the pepino mosaic virus into necrotic one. Virus Res. 2011, 159, 57-61. [CrossRef] [PubMed]

117. Hasiow-Jaroszewska, B.; Borodynko, N.; Pospieszny, H. Genetic and biological variability of pepino mosaic virus isolates infecting tomato plants. Phytopathology 2011, 101, S70.

118. Hasiow-Jaroszewska, B.; Jackowiak, P.; Borodynko, N.; Figlerowicz, M.; Pospieszny, H. Quasispecies nature of pepino mosaic virus and its evolutionary dynamics. Virus Genes 2010, 41, 260-267. [CrossRef]

119. Hasiow-Jaroszewska, B.; Kuzniar, A.; Peters, S.A.; Leunissen, J.A.M.; Pospieszny, H. Evidence for RNA recombination between distinct isolates of pepino mosaic virus. Acta. Biochim. Pol. 2010, 57, 385-388. [CrossRef]

120. Hasiow-Jaroszewska, B.; Paeleman, A.; Ortega-Parra, N.; Borodynko, N.; Minicka, J.; Czerwoniec, A.; Thomma, B.P.H.J.; Hanssen, I.M. Ratio of mutated versus wild-type coat protein sequences in pepino mosaic virus determines the nature and severity of yellowing symptoms on tomato plants. Mol. Plant Pathol. 2013, 14, 923-933. [CrossRef] [PubMed]

121. Hasiow-Jaroszewska, B.; Pospieszny, H.; Borodynko, N. New necrotic isolates of pepino mosaic virus representing the $\mathrm{CH} 2$ genotype. J. Phytopathol. 2009, 157, 494-496. [CrossRef]

122. Van der Vlugt, R.A.A.; Stijger, C.C.M.M. Pepino mosaic virus. In Encyclopedia of Virology; Mahi, B.W.J., Van Regenmortel, M.H.V., Eds.; Academic Press: Salt Lake City, UT, USA, 2008; pp. 103-108. [CrossRef]

123. De Nayer, F.; Goen, K.; Paeleman, A.; Parra, N.O.; Vanachter, A.C.R.C.; Hanssen, I.M.; Wittemans, L.; Vandewoestijne, E. CROSS-PROTECTION AS A CONTROL STRATEGY FOR PEPINO MOSAIC VIRUS (PEPMV) IN GREENHOUSE TOMATO. Acta. Hortic. 2011, 914, 163-169. [CrossRef]

124. Hasiow-Jaroszewska, B.; Minicka, J.; Pospieszny, H. Cross-protection between different pathotypes of pepino mosaic virus representing Chilean 2 genotype. Acta. Sci. Pol-Hortorum 2014, 13, 177-185.

125. Mih, C.G. Engineering Plant Virus "Vaccines" Using Pepino Mosaic Virus as a Model. Ph.D. Thesis, The Ohio State University, Columbus, OH, USA, 2013.

126. European Food Safety Authority. Conclusion on the peer review of the pesticide risk assessment of the active substance pepino mosaic virus strain CH2 isolate 1906. EFSA J. 2015, 13, 3977. [CrossRef]

127. Pmv@-01 | Vaccination against PepMV Damage on Tomatoes. Available online: http://pmv-01.com/en/ \#what-is-pmv-01 (accessed on 30 May 2019).

128. European Food Safety Authority. Conclusion on the peer review of the pesticide risk assessment of the active substance Mild Pepino mosaic virus isolate VX1. EFSA J. 2015, 15, 4650. [CrossRef]

129. Valto-Dedicated in the World of Natural Crop Protection. Available online: https://www.valto.nl/en (accessed on 18 June 2019).

130. Wilstermann, A.; Ziebell, H. 2019: Tomato brown rugose fruit virus (ToBRFV). JKI Data Sheets Plant Dis. Diagn. 2019, 1, 1-4. [CrossRef]

131. Pooggin, M.M. Small RNA-omics for plant virus identification, virome reconstruction, and antiviral defense characterization. Front. Microbiol. 2018, 9, 2779. [CrossRef] [PubMed] 
132. Voinnet, O. RNA silencing as a plant immune system against viruses. Trends Genet. 2001, 17, 449-459. [CrossRef]

133. Bhattacharjee, S.; Zamora, A.; Azhar, M.T.; Sacco, M.A.; Lambert, L.H.; Moffett, P. Virus resistance induced by NB-LRR proteins involve Argonaute4-dependent translational control. Plant J. 2009, 58, 940-951. [CrossRef]

134. Sanfaçon, H. Plant Translation Factors and Virus Resistance. Viruses 2015, 7, 3392-3419. [CrossRef] [PubMed]

135. Ziebell, H.; Payne, T.; Berry, J.O.; Walsh, J.A.; Carr, J.P. A cucumber mosaic virus mutant lacking the 2b counter-defence protein gene provides protection against wild-type strains. J. Gen. Virol. 2007, 88, 2862-2871. [CrossRef] [PubMed]

136. Dietrich, C.; Maiss, E. Fluorescent labelling reveals spatial separation of potyvirus populations in mixed infected Nicotiana benthamiana plants. J. Gen. Virol. 2003, 84, 2871-2876. [CrossRef] [PubMed]

137. Ziebell, H.; Carr, J.P. Effects of dicer-like endoribonucleases 2 and 4 on infection of Arabidopsis thaliana by cucumber mosaic virus and a mutant virus lacking the $2 \mathrm{~b}$ counter-defence protein gene. J. Gen. Virol. 2009, 90, 2288-2292. [CrossRef] [PubMed]

138. Takeshita, M.; Shigemune, N.; Kikuhara, K.; Furuya, N.; Takanami, Y. Spatial analysis for exclusive interactions between subgroups I and II of cucumber mosaic virus in cowpea. Virology 2004, 328, 45-51. [CrossRef]

139. De Zoeten, G.A.; Fulton, R.W. Understanding generates possibilities. Phytopathology 1975, 65, $221-222$.

140. Zaitlin, M. Viral cross-protection: More understanding is needed. Phytopathology 1976, 66, 382-383. [CrossRef]

141. Folimonova, S.Y.; Robertson, C.J.; Shilts, T.; Folimonov, A.S.; Hilf, M.E.; Garnsey, S.M.; Dawson, W.O. Infection with strains of citrus tristeza virus does not exclude superinfection by other strains of the virus. J. Virol. 2010, 84, 1314-1325. [CrossRef]

142. Harper, S.J.; Cowell, S.J.; Dawson, W.O. Isolate fitness and tissue-tropism determine superinfection success. Virology 2017, 511, 222-228. [CrossRef]

143. Costa, A.T.; Nunes, W.M.D.; Zanutto, C.A.; Muller, G.W. Stability of citrus tristeza virus protective isolates in field conditions. Pesqui. Agropecu. Bras. 2010, 45, 693-700. [CrossRef]

144. Scott, K.A.; Hlela, Q.; Zablocki, O.; Read, D.; van Vuuren, S.; Pietersen, G. Genotype composition of populations of grapefruit-cross-protecting citrus tristeza virus strain gfms12 in different host plants and aphid-transmitted sub-isolates. Arch. Virol. 2013, 158, 27-37. [CrossRef] [PubMed]

145. Harper, S.J.; Cowell, S.J.; Dawson, W.O. With a little help from my friends: Complementation as a survival strategy for viruses in a long-lived host system. Virology 2015, 478, 123-128. [CrossRef] [PubMed]

146. Syller, J.; Grupa, A. The effects of co-infection by different potato virus y (PVY) isolates on virus concentration in solanaceous hosts and efficiency of transmission. Plant. Pathol. 2014, 63, 466-475. [CrossRef]

147. Folimonova, S.Y. Superinfection exclusion is an active virus-controlled function that requires a specific viral protein. J. Virol. 2012, 86, 5554-5561. [CrossRef] [PubMed] 